\title{
EFL Learners'Writing Self-efficacy and Relationship with Metacognitive Strategies*
}

\author{
Ting Sun \\ The Faculty of Humanities and Foreign Languages \\ Xi'an University of Technology \\ Xi'an, China
}

\begin{abstract}
The present study investigated EFL learners writing self-efficacy and their metacognition. 97 English major students from a university were selected as participants. Two questionnaires assessing learners'self-efficacy and metacognitive strategies were administered. The study found that high achieving students had high self-efficacy level and high metacognition, while low achieving students had low selfefficacy and low metacognition. Besides, self-efficacy and metacognition are significantly positive corrrelated. This study has theoretical as well as pedagogical implications. EFL teachers should enhance learners'self-efficacy and train their metacognitive strategies so as to improve their writing achivements.
\end{abstract}

Keywords-self-efficacy; metacognition; EFL; English writing

\section{INTRODUCTION}

As one of the five basic skills in language learning, English writing that can really embody EFL learners'comprehensive and integrative linguistic proficiency, is the most sophisticated and difficult one for them to acquire because writing is not a linear process but a recursive one, which involves not only intra-linguistic elements such as lexical, syntactic and discoursal factors but also includes inter-linguistic elements as writing purposes, target readers and writers'cognitive development. Many writing instruction approaches are adopted with an aim to promote writing competence of EFL students, such as genre-based writing approach and product-oriented approach, which are productcentered and regardless of learners'cognitive development. Therefore, a more comprehensive approach is needed to be employed in the classroom setting. Writing is a complex process involving different factors, among which selfefficacy and language learning strategy are two salient ones affecting learners'writing proficiency. As one category of learning strategies, metacognitive strategies aroused people's attention. Considerable research has shown that proper use of metacognitive strategies has positive influence on learners language performance (Oxford \& Crookall, 1989; Oxford \& Burry-stock, 1995; O’Malley \& Chamot, 1990/1999/2001;

*This study has been supported by Xi'an University of Technology ("Weblog-assisted cooperative English writing model", Project No.: xqj1414), by Education Department of Shaanxi Provincial Governmen ("Translation and circulation of contemporary literature of Shaanxi within the framework of Maletzke's theory of mass communication", Project No.: $16 \mathrm{KJ} 1523)$.
Arnold, 2000). Self-efficacy has also evoked great interest among educational psychologists, and many studies have proven its effect on academic performance and students'language gains (Pajares \& Johnson, 1996; Zimmerman \& Bandura, 1994). However, research on metacognitive strategies and self-efficacy in the context of EFL learners'writing is rare and a few identified studies correlate them and find out inherent connection between them. Therefore, this study aims to investigate SFL learners'use of metacognitive strategies and their English writing self-efficacy profiles and to examine the correlation between the two aspects.

\section{LITERATURE REVIEW}

\section{A. Self-efficacy}

Since Bandura first introduced the concept of selfefficacy, it has received extensive supports from a growing system of findings from diverse fields. Many studies have proved that self-efficacy exerts considerable influence on the academic achievements of a learner (Zimmerman \& Bandura, 1994; Pajares \& Johnson, 1996). Individuals with strong efficacy beliefs evaluate themselves as a capable of effective performance, while with weak sense of efficacy evaluate themselves as less capable (Pajaries, 2009). Researchers have also reported that efficacy beliefs affected the career choices of individuals, particularly in science and mathematics (Pajaries, 2003). Findings revealed that selfefficacy beliefs of teachers were related to their instructional practice and the academic progress of their students (Pajaries \& Valiante, 1997). Some studies claimed that students'self efficacy beliefs were positively correlated with their autonomous learning capability (Li \& Yu, 2008; Yan, 2010; Tao, 2013; Liu, 2014; Xu \& Li, 2014) and their learning motivation (Qin \& Wen, 2002; Wu, \& Zhang, 2009). Therefore, it is critical to improve students'self-efficacy beliefs to facilitate their language acquisition (Wang, Schwab, Fenn, \& Chang, 2013). The reliability and validity of self-efficacy scales have also been studied and discussed to provide valid instruments for measuring learners'selfefficacy (Wang, Hu, \& Liu, 2001; Wang, Kim, Bai, \& Hu, 2014). Writing self-efficacy is defined as students'selfevaluation of their own writing skills (McCarthy, Meier \& Rinderer, 1985). It is also regarded as individuals'judgment of their competence in writing, specifically their ability to write different wiring tasks and of their possession of 
varying composition, usage, and mechanical skills (Pajares, 2003). Some researchers have confirmed that students'selfefficacy in their writing skills is positively related to their writing performance (McCarthy, Meier \& Rinderer, 1985; Shell, et al., 1989; Pajares \& Johnson, 1996; Pajares \& Valiante, 1997; Tang, \& Xu, 2011; Li, Liu, \& Liu, 2013; Yan, \& Zhang. 2015). Other researchers explored the writing self-efficacy differentiation among students of different genders and ages (Shell, Colvin \& Bruning, 1995; Pajares and Johnson, 1996).

\section{B. Megacognitive Strategies}

Metacognition was defined as self-cognition of an individual's own activity, consisting of two important elements, metacognitive knowledge and metacognitive strategies (Flavell, 1976). Metacognitive strategies were divided into three groups, centering, arranging and Planning, evaluating (Oxford, 1989). They were also been classified into seven subsets including superior organization, evectional focus, directed focus, self-monitoring, selfmanagement and problem viewing (O'Malley \& Chamot, 1990). A series of studies found positive correlation between the use of metacognitive strategies and students'performance in their learning. It was claimed that metacognitive strategy trainings play a significant role in the improvement of learning (O'Malley et al., 1985). Holec (1987) showed that there is a correlation between the changes of learners' learning beliefs and their evaluation and planning. Students'metacognitive knowledge also has considerable influence on the feasibility their learning approaches (Wenden, 1995). Besides, some specific instructions in second language learning and language strategy use did influence learners'speaking ability (Cohen, 2000). However, the study conducted by Purpura showed that there was no lucid evidence to prove that there was a correlation between metacognitive processing and students'learning (Purpura, 1997). There is a substantial body of research on selfefficacy and learning strategies, but studies on the relationship between metacognitive strategies and English writing self-efficacy are rare. Based on the framework of the previous studies, this present study sets out to examine the questions as follows.

- Are there any writing self-efficacy differences among high, intermediate and low achieving students?

- Are there any differences in the use of metacognitive strategies among high, intermediate and low achieving students?

- What is the relationship betweem EFL learners'use of metacognitive strategies and their writing selfefficacy?

\section{METHODOLOGY}

\section{A. Participants}

97 English major sophomores are randomly selected by convenient sampling from the Faculty of Humanities and Languages in Xi'an University of Technology: 82 (84\%) males, $15(16 \%)$ females, aging from 19 to 22 years old. Their years of English learning range from 7 to 14 years. All the students were classified into three groups: high, intermediate and low according to a writing test which was held before the study. The high group consists 30 students, intermediate 47 and low 20 students.

\section{B. Instruments}

The Questionnaire of Metacognitive Strategies in English Writing is designed based on the metacognitive strategy classification system (O' Malley \& Chamot, 2001), which contains 27 items and is measured on a 5-point rating scale from 1 (never) to 5 (always), aiming at obtaining the information of students'metacognitive strategy use in writing (see Appendix 1). The Questionnaire of English Writing Self-efficacy is formulated according to Pajares et al. (2000), aiming at testing students'writing self-efficacy beliefs, which consist of 10 items, all of which are measured on a 5-point rating scale from 1 (no chance) to 5 (completely sure) (see Appendix 2). The two questionnaires have been translated into Chinese. Two semi-structured face-to-face interviews are employed before and after the training respectively to obtain more data about the students' perspectives on the use of metacognitive strategies and self-efficacy in the process of writing. Ten subjects from the experimental group and ten from the control group will be invited to state their responses to ten open-ended questions. One writing test is assigned to students before the dtudy as the pre-test to measure their English writing proficiency and give them a classification. The writing test is consistent with the writing part in the TEM-4 (Test for English Majors Band 4) in terms of forms and difficulty. Three teachers in the English Department who are not involved in the study are chosen to assess all the students'writings in order to avoid.

Subtle individual biases and increase the credibility and validity of the study. The three raters who are involved in the writing assessment need to be trained and the scoring criteria of TEM-4 are considered to be the main reference rules for the evaluation. The total score of each task is 15 points and two teachers rate all the compositions. If the score of an essay has a gap of 2 points between the two raters, then the third rater will rate it again. The mean of the three raters'scores will be the final result.

\section{DATA ANALYSIS AND DISCUSSION}

TABLE I. SELF-EFFICACY DIFFERENCES

\begin{tabular}{|l|c|c|c|}
\hline \multicolumn{1}{|c|}{ Writing levels } & \multicolumn{1}{c|}{ N } & M & SD \\
\hline HIgh & 30 & 3.89 & .586 \\
\hline intermediate & 47 & 3.01 & .623 \\
\hline Low & 20 & 2.45 & .547 \\
\hline
\end{tabular}

As shown in "Table I", high level acheving students have high self-efficacy (3.89 on average). By contrast, low writng level students have lowest self-efficacy, only 2.45 . This result shows that writing scores have positive correlation with self-efficacy levels. High achieving students have more confidence. They are likely to persevere in chanllenging tasks, which low-achieving students would choose to withdraw when difficulties arise. Therefore, in the classroom taching, teachers should try to make students highly motivated, enhance their interest in teaching materials and 
promote their self-efficacy, which will in turn increase their writing achievements.

TABLE II. METACOGNITION DIFFERENCES

\begin{tabular}{|l|l|l|l|l|l|l|l|}
\hline \multicolumn{2}{|c|}{} & \multicolumn{2}{|c|}{ High } & \multicolumn{2}{c|}{ Intermediate } & \multicolumn{2}{c|}{ Low } \\
\cline { 2 - 8 } \multicolumn{2}{|c|}{} & M & SD & M & SD & M & SD \\
\hline \multirow{2}{*}{$\begin{array}{c}\text { Metaco } \\
\text { gnition }\end{array}$} & Plan & 4.02 & .325 & 3.22 & .857 & 2.01 & .641 \\
\cline { 2 - 8 } & Monitor & 3.75 & .528 & 2.58 & .570 & 2.25 & .598 \\
\cline { 2 - 8 } & Regulate & 3.29 & .423 & 3.01 & .506 & 2.14 & .595 \\
\hline
\end{tabular}

"Table II" shows the metacognition differences among high, intermediate and low writing categories. Metacognition has been subclassified in three categories: planning, monitoring and regulating abilities. Students with high writing levels are good in metacognition while poor achieving students are low in planning, monitoring and regulating in the process of writing. This suggests that EFL learners should be trained to equip themselves with relevant metacognitive awareness and abilities. They are expected to learn some strategies such as planning their time, making outline, make schedule, monitoring time and attention, regulate and review, ect..

TABLE III. CORRELATION BETWEEN SELF-EFFICACY AND METACOGNITION

\begin{tabular}{|c|l|l|l|l|}
\hline & Self-efficacy & Plan & Monitor & Regulate \\
\hline Self-efficacy & & $*$ & $*$ & $*$ \\
\hline Plan & .224 & $*$ & $*$ & $*$ \\
\hline Monitor & .235 & .268 & $*$ & $*$ \\
\hline Regulate & .467 & .361 & .338 & $*$ \\
\hline
\end{tabular}

"Table III" gives a clear indication that self-efficacy have significantly positive correlation with metacognition. Writing process is complex and all the elements are interwined with each other and all play a part in the writing achievements. Students with high self-efficacy have more metacognitive strategies and students with low self-efficacy are lack of metacognition. They are closely associated with each other and contribute to the EFL learneres'writing achievement.

\section{CONCLUSION}

The present study investigated EFL learners writing selfefficacy and metacognition. College level students were shosen as the participants. The study found that high achieving students have high self-efficacy level and high metacognition, while low achieving students have low selfefficacy and low metacognition. Besides, self-efficacy and metacognition are significantly positive corrrelated. This study has pedagogical implications. EFL teachers should enhance learners'self-efficacy and train their metacognitive strategies so as to improve their writing achivements.

\section{REFERENCES}

[1] Arnold, J. (Ed.) (2000). Affect in Language Learning. Beijing: Foreign Language Teaching and Research Press.

[2] Cohen, A. D. (2000). Strategies in Learning and Using a Second Language. Beijing: Foreign Language Teaching and Research Press.

[3] Ellis, R. (2003). Task-based language Learning and Teaching. Oxford: Oxfor University Press.
[4] Ellis, R. and G. Barkhuizen. (2005). Analysing Learner Language. Oxford: Oxford University Press.

[5] Ellis, R. (2008). The Study of Second Language Acquisition (2ed edition). Oxford: Oxford University Press.

[6] Flavell, J. H. (1976). Metacognitive aspects of problem solving. In: L. B. Resnick (Ed.). The Nature of Intelligence. Hillsdale. NJ: Erlbaum.

[7] Holec, H. (1987). The learner as manager: managing learning or managing to learn. In A. Wenden, \& J. Rubin (Eds.). Learner Strategies in Language Learning. London: Prentice Hall International.

[8] Li, H., Liu, R., \& Liu, Y. (2013). The mediating effects of EFL writing self-efficacy on the relationship between EFL writing anxiety and writing performance for college students. Psychological Development and Education, 4, 385-390.

[9] Li, K., \& Yu, L. (2008). The relationship between learning motivation, self-efficacy, attribution and autonomous learning behavior. Theory and Practice of Foreign Language Teaching, 2, 1-5.

[10] Liu, P. (2014). The relationship between self-efficacy and learner autonomy in college English learning and countermeasures for promotion. Computer-assisted Foreign Language Education, 158, 7579.

[11] McCarthy P. Meier, S., Rinderer R. Self-efficacy and writing. (1985). College Composition and Communication, 36(4).

[12] O'Malley, J. M., Chamot, A. U., Stewner-Mazanaren, G., Russo, R., \& Kupper, L. (1985). Learning strategies applications with students of English as second language. TESOL Quarterly, 19, 285-296.

[13] O'Malley. J. M. \& Chamot, A. U. (1990/1999/2001). Learning Strategies in Second Language Acquisition. Shanghai: Shanghai Foreign Language Education Press.

[14] Oxford, R. L., \& Crookall, D. (1989). Research on language learning strategies: 3methods, findings, and instructional issues. Modern Language Journal 73: 403-419.

[15] Oxford, R. L., \& Burry-stock. (1995). Assessign the use of language learning strategies worldwide with the ESL/EFL version of the strategy inventory for language learning (SILL). System, 23, 1-23.

[16] Pajares, F., \& Johnson, M. J. (1996). Self-efficacy beliefs and the writing performance in entering high school students. Psychology in the Schools 33: 163-175.

[17] Pajares, F., \& Valinante, G. (1997). Influence of self-efficacy on elementary students'writing. The Journal of Educational Research, 90

[18] Pajares, F. (2003). Self-efficacy beliefs, motivation and achievement in writing: a rewiew of the literature. Reading and Writing Quarterly, 19.

[19] Purpura, J. E. (1997). An analysis of the relationships between test takers'cognitive and metacognitive strategy use and second language test performance. Language Learning, 2, 289-325.

[20] Qin, X., \& Wen Q. (2002). The inner structure of learning motivation for non-English major college students. Foreign Language Teaching and Research, 1, 51-58.

[21] Shell, D. F., Murphy, C. C., \& Bruning, R. H. (1989). Self-efficacy and outcome expectancy mechanism in reading and writing achievement. Journal of Educational Psychology, 81.

[22] Shell, D. F., Colvin, C., \& Bruning, R. H. (1995). Self-efficacy, attribution, and outcome expectancy mechanism in reading and writing achievement: grade-level and achievement. Journal of Educational Psychology, 87(3).

[23] Skehan, P. 1998. A Cognitive Approach to Language Learning. Oxford University Press.

[24] Tang, F., \& Xu J. (2011). The research and study of college students'English writing self-efficacy. Foreign Language World, 6, 22-29.

[25] Tao, J,. (2013). The study of autonomous English learning in the internet context based on the constructivism theory. Foreign Language Research, 3, 54-58.

[26] Wang, C., Hu, Z., \& Liu, Y. (2001). Evidences for reliability and validity of the Chinese version of General Self-efficacy Scale. Chinese Journal of Applied Psychology, 7 (1), 37-40. 
[27] Wang, C., Kim, D.-H., Bai, R., \& Hu, J. (2014). Psychometric properties of a self-efficacy scale for English language learners in China. System, 44, 24-33.

[28] Wang, C., Schwab, G., Fenn, P., \& Chang, M. (2013). Self-efficacy and self-regulated learning strategies for English language learners: Comparison between Chinese and German college students. Journal of Enducational and Developmental Psychology,3(1)(Retrieved from http:

[29] www.ccsenet.org/journal/index.php/jedp/article/view/26477).

[30] Wenden, A. L. (1995). Learner training in context: a knowledgebased approach. System, 23,183-194.

[31] Wu, X., \& Zhang, Q. (2009). The relationship between self-efficacy, learning strategies, autonomous learning ability and academic achievement. Foreign Language Education, 30 (3), 43-46.

[32] Xu, Ji., \& Li, B. (2014). Effects of EFL learner controllable factors on college students'autonomous English learning ability. Modern Foreign Language, 37(5), 647-656.

[33] Yan, M. (2010). An empirical study of the cultivation of autonomous learning ability of college English students. Computer-assisted Foreign Language Education, 132, 48-51.

[34] Yan, R., \& Zhang, L. (2015). The effect of complexity and difficulty of tasks, and self-efficacy on English writing. Foreign Language World, 1, 40-47.

[35] Zimmerman, B. J., \& Martinez-Pons, M. (1986). Development of a structured interview for assessing student use of self-regulated learning strategies. American Educational Research Journal, 23.

[36] Zimmerman, B. J., \& Bandura, A. (1994). Impact of self-regulatory influences on writing course attainment. American Educational Research Journal, 29, 663-676. 